\title{
EFFECT OF IRRIGATION REGIMES ON POTATO PRODUCTIVITY IN SANDY SOILS UNDER SPRINKLER AND DRIP IRRIGATION SYSTEMS
}

\author{
M.M. Attia, A.K. Abd El-Halim, A.M. Osman, M.A. Sayed and H.E. Khalifa \\ Water Requirements and Field Irrigation Research Department; Soils, Water and Environment \\ Research Institute (SWERI); Agric. Res. Center (ARC); Giza; Egypt
}

Received: Apr. 18, 2017

Accepted: May 14, 2017

\begin{abstract}
A field experiment was conducted at Ali Mubarak agricultural research station $\left(30^{\circ} 35^{\prime} \mathrm{N}, 30^{\circ} 15^{\prime} \mathrm{E}\right.$, and $32 \mathrm{~m}$ above sea level), El-Bustan area, El-Behiera Governorate, Egypt in winter seasons of 2008-2009 and 2009-2010. The aim was to study the effect of four irrigation regime $s\left(I_{1}=\right.$ irrigation with amount of water equals $125 \%$ of potential evapotranspiration (ETp) determined by class A pan, 100\% ETp, 75\% ETp, and 50\% ETp), and two irrigation systems (sprinkler and drip) on potato fresh yield, potato dry matter, starch percentage, water requirements, water consumption, and water utilization efficiency (WUtE), as well as developing local potato crop coefficient $(K c)$. A split plot experimental design with four replicates was used. The main plots were assigned to the irrigation systems (drip and sprinkler), and the sub-plots were assigned to the irrigation treatments. Potato (Spunta variety) was used in the present experiment. Results revealed that drip irrigation recorded significant increase in fresh potato yield by 23.0 and $7.0 \%$ in the $1^{\text {st }}$ and $2^{\text {nd }}$ seasons, respectively as compared with sprinkler irrigation system. Under the experimental conditions, that potato fresh yield increases by increasing amount of irrigation water up to $E T p_{125 \%}$ in the two growing seasons. The highest yields of potato were 14.325 and 17.902 tonfed $d^{-1}$ in the $1^{\text {st }}$ and $2^{\text {nd }}$ seasons, respectively, were obtained from ETp ${ }_{125 \%}$ irrigation regime with drip irrigation system. The $E T p_{125 \%}$ irrigation regime produced the highest values of potato dry mater and starch\% reached (2.358 and 2.975 tonfed $\left.{ }^{1}\right)$ and $(18.8$ and $18.5 \%)$, respectively, in the $1^{\text {st }}$ and $2^{\text {nd }}$ seasons. The highest fresh potato yields e.g. 14.325 and 17.902 tonfed $^{-1}$ were obtained with $E T p_{125 \%}$ irrigation regime under drip system, in the $1^{\text {st }}$ and $2^{\text {nd }}$ growing seasons, respectively. Seasonal water requirements for potato crop under drip irrigation system were 35.0 and $38.6 \mathrm{~cm}$ in the $1^{\text {st }}$ and $2^{\text {nd }}$ seasons, respectively. Seasonal water consumptive use values for potato crop under drip irrigation system were 27.8 and $32.0 \mathrm{~cm}$ in the in the $1^{\text {st }}$ and $2^{\text {nd }}$ seasons, respectively. The highest WUtE average value of $11.37 \mathrm{~kg}$ potato $y i e l d / \mathrm{m}^{3}$ applied water resulted from the interaction between $E T p_{100 \%}$ irrigation regime and the drip irrigation system. The 2-year average value of local potato crop coefficient (Kc) was 0.81 under drip irrigation.
\end{abstract}

Key words: Sprinkler and drip irrigation systems, irrigation regimes, Seasonal water consumptive use, Seasonal water requirements, potato fresh and dry potato yields, Crop coefficient $(K c)$

\section{INTRODUCTION}

Water scarcity is a vital problem confronts farmers and agricultural scientists in the irrigated areas of arid and semi-arid regions. Knowledge of the proper amounts of irrigation water is essential to maximize yield of different crops. Improper irrigation water management accounts for significant water losses in some large irrigation schemes. Consequently, the use of modern and highly efficient irrigation systems in irrigation operation and scheduling is essential for the reduction of irrigation water demands (Brown, 1999). Potato (Solanum tuberosum L.) is considered one of the most important vegetable crops all over the world (Rowe, 1993). The ideal conditions for potato growth include high and nearly 
constant soil matric potential, high soil oxygen diffusion rate, adequate incoming radiation, and optimal soil nutrients. Among the environmental factors, soil water is a major limiting factor in the production and quality of potatoes. Many irrigation experiments have shown that potato is relatively sensitive to moisture stress (Porter et al., 1999; and Faberio et al., 2001). The successful irrigation management of potato requires knowledge of both amounts of irrigation water and scheduling methods. Improved irrigation methods can save water without compromising potato yield or quality (Zeag, 1991). Potato tuber yield and quality can be reduced by water stress occurring at any time during the growing seasons (Adams and Stevenson, 1990). The least amount of water required to produce high potato yield in the new land was obtained under drip irrigation system. The net profit from crop production with drip irrigation system was $14.8 \%$ less than the profit from sprinkler irrigation system (Zeag, 1991). Water use efficiency of a potato variety produced from surface drip irrigation was higher than tha $t$ of sprinkler irrigation system (Badr, 1992). A widely adopted method for estimating crop consumptive water use (CWU) is the evaporation pan method, which relates evaporation from Class A Weather Bureau evaporation pan to CWU. These two quantities are related by what is called crop coefficient (Kc). The crop coefficient represents crop specific water use and is essential for accurate estimation of irrigation requirements of different crops in the irrigated area (CSSRI, 2000). Irrigation scheduling based on the $\mathrm{Kc}$ is one of the simplest methods where no sophisticated instrument is required. Based on the US Weather Service Class A pan evaporation, many studies on the irrigation of potato have been completed (Ferreira and Carr, 2002; and Panigrahi et al., 2001). The trends of water use efficiency (WUE) showed that the lower the amount of irrigation water received, the higher the water use efficiency obtained for the drier plant biomass and the tuber yields (Yuan et al., 2003). On the loamy and sandy loam soils, tuber yields were reduced by deficit irrigation corresponding to $70 \%$ and $74 \%$ of evapotranspiration in sprinkler and trickle irrigation systems, respectively. Water use of potato crop ranged from 490 to $760 \mathrm{~mm}$ for trickle- irrigated plots and from 565 to 830 $\mathrm{mm}$ for sprinkler- irrigated treatments (Ünlü et al., 2006). Erdem et al. (2006) with potato grown under furrow and drip irrigation methods and irrigation regimens 30,50 , or $70 \%$ of the available water was consumed, found that seasonal evapotranspiration ranged from 501 to $683 \mathrm{~mm}$ in 2003 and from 464 to $647 \mathrm{~mm}$ in 2005. In addition, furrow and drip irrigation had no significant effect on tuber yield in both seasons. Irrigation regimens influenced tuber yield, where in 2005 the highest tuber yield was registered for $30 \%$ irrigation depletion regimen reaching $35.13 \mathrm{t} \mathrm{ha}^{-1}$ in 2003 and $44.56 \mathrm{t} \mathrm{ha}^{-1}$ in 2005. Furthermore, water use efficiency values increased from 4.70 to 6.63 $\mathrm{kg} \mathrm{m}^{-3}$ for furrow-irrigated treatments and from 5.19 to $9.47 \mathrm{~kg} \mathrm{~m}^{-3}$ for drip irrigated ones. Ayes and Korukeu (2010) reported that, the amounts of irrigation water applied to the potato plants were between 399 and $655 \mathrm{~mm}$ in the first year, and between 370 and $646 \mathrm{~mm}$ in the second year, and plant water consumption varied from 345 to 585 $\mathrm{mm}$. The authors found that the highest yields of $32.3 \mathrm{t} \mathrm{ha}^{-1}$ and $35.0 \mathrm{t} \mathrm{ha}^{-1}$ were obtained from full irrigation imposed at all growth periods, while the lowest yields of $12.1 \mathrm{t} \mathrm{ha}^{-1}$ and $10.9 \mathrm{t} \mathrm{ha}^{-1}$ were reported from the $50 \%$ water deficiency applied at all growth periods. The highest values of water use efficiency (WUE) and irrigation water use efficiency (IWUE) of 5.23 and $4.35 \mathrm{~kg} \mathrm{~m}^{-3}$, respectively, were reported for applying deficit irrigation only at ripening period and full irrigation at all other stages. Kandil et al. (2011) found that, irrigation at $54 \%$ moisture from field capacity produced maximum values of potato yield and its components. Eskandaria et al. (2012) indicated that, full irrigation regime, which provides $100 \%$ of 
the water requirement of potato (Agria and Almeria cultivars) had the highest yield and water productivity under drip irrigation system.

The objectives of the present research were to study the effect of the amounts of applied irrigation water under sprinkler and drip systems on potato fresh yield, dry matter yield, tuber starch percentage, water requirements, water consumptive use, and water utilization efficiency, and to develop potato crop coefficient under local conditions.

\section{MATERIALS AND METHODS}

A field experiment was conducted at Ali Mubarak agricultural research station (30 $35^{\prime} \mathrm{N}, 30^{\circ} 15^{\prime} \mathrm{E}$, and $32 \mathrm{~m}$ above sea level), El-Bustan area, El-Behiera Governorate, Egypt during 2008-2009 and 2009-2010 winter growing seasons. The experimental site represents the newly reclaimed sandy soils where modern irrigation systems (drip and sprinkler) are introduced to the region. Particle size distribution, bulk density and some hydro-physical parameters of the experimental soil are shown in Table 1.

A split plot experimental design with four replicates was adopted. The main plots were assigned to two irrigation systems (drip and sprinkler), and four irrigation regimes were represented in the sub-plots. The adopted irrigation regimes were as follows:

$\mathrm{l}_{1}=$ irrigation with amount of water equals $125 \%$ of potential evapotranspiration $\left(\mathrm{ETp}_{125 \%}\right)$.

$\mathrm{I}_{2}=$ irrigation with amount of water equals $100 \%$ of ETp, $\left(\mathrm{ETp}_{100 \%}\right)$

$\mathrm{I}_{3}=$ irrigation with amount of water equals $75 \%$ of $E T p .\left(E T p_{75 \%}\right)$

$\mathrm{I}_{4}=$ irrigation with amount of water equals $50 \%$ of ETp. $\left(\mathrm{ETp}_{50 \%}\right)$

Irrigation water was applied in 3 and 6 days- interval under drip and sprinkler systems, respectively, and irrigation water quantities were based ETp value to ensure the proper germination. The adopted irrigation regimes were applied after complete plant ${ }^{\text {'s }}$ establishment.

Potential evapotranspiration (ETp) values were calculated based on class A pan records as follows:

ETp $=$ Epan $*$ Kpan, Doorenbos and Pruitt, 1984

where:

Epan = measured class $\mathrm{A}$ pan evaporation values, $\left(\mathrm{mm} \mathrm{d}^{-1}\right)$

Kpan = pan coefficient that equals 0.75 for the experimental site.

Table 1. Particle size distribution and some hydro-physical parameters of the experimental soil

\begin{tabular}{|l|c|c|c|c|c|c|c|c|}
\hline \multirow{2}{*}{$\begin{array}{l}\text { Soil } \\
\text { depth } \\
(\mathrm{cm})\end{array}$} & \multicolumn{3}{|c|}{$\begin{array}{c}\text { Particle size } \\
\text { distribution }\end{array}$} & \multirow{2}{*}{$\begin{array}{c}\text { Textural } \\
\text { Sand } \\
\end{array}$} & $\begin{array}{c}\text { Silt } \\
(\%)\end{array}$ & $\begin{array}{c}\text { Clay } \\
(\%)\end{array}$ & & \multicolumn{3}{c|}{ Hydro-physical parameters } & \multirow{2}{*}{$\begin{array}{c}\text { Field } \\
\text { capacity } \\
(\%, \mathrm{w} / \mathrm{w})\end{array}$} & $\begin{array}{c}\text { Wilting } \\
\text { point } \\
(\%, \mathrm{w} / \mathrm{w})\end{array}$ & $\begin{array}{c}\text { Available } \\
\text { water } \\
(\%, \mathrm{w} / \mathrm{w})\end{array}$ & $\begin{array}{c}\text { density } \\
\left(\mathrm{g} \mathrm{cm}^{-3}\right)\end{array}$ \\
\hline $00-15$ & 91.5 & 3.5 & 5.0 & sandy & 8.8 & 4.7 & 4.1 & 1.44 \\
\hline $15-30$ & 91.9 & 3.2 & 4.9 & sandy & 8.7 & 4.6 & 4.1 & 1.63 \\
\hline $30-45$ & 92.0 & 3.0 & 5.0 & sandy & 8.5 & 4.5 & 4.0 & 1.70 \\
\hline $45-60$ & 92.5 & 2.8 & 4.7 & sandy & 8.3 & 4.4 & 3.9 & 1.75 \\
\hline Average & 92.0 & 3.1 & 4.9 & sandy & 8.6 & 4.6 & 4.0 & 1.63 \\
\hline
\end{tabular}


The amounts of irrigation water were calculated according to the equation given by Vermeiren and Jopling (1984) as follows:

where:

$$
A I W=\frac{E T p * K c * I}{E a(1-L R)}
$$

AIW = depth of applied irrigation water $(\mathrm{mm})$ $\mathrm{ETp}=$ potential evapotranspiration $\left(\mathrm{mm} \mathrm{d}^{-1}\right)$ $\mathrm{Kc}=$ calculated crop coefficient values at the experimental site

I = irrigation intervals (days)

$\mathrm{Ea}=$ irrigation application efficiency of the drip and sprinkler irrigation systems.

$\mathrm{LR}=$ leaching requirements, not considered under the present experiment.

Irrigation time for drip irrigation system was determined before an irrigation event by measuring the actual emitter discharges according the equation given by Ismail (2002) as follows:

$t=\frac{A I W \times A}{q}$

where:

$\mathrm{t}=$ irrigation time (hour)

$A=$ wetted area $\left(\mathrm{cm}^{2}\right)$

$\mathrm{q}=$ emitter discharge $\left(\mathrm{Lh}^{-1}\right)$

AIW = applied irrigation water $(\mathrm{cm})$

The irrigation time for sprinkler irrigation system was calculated according to the following equation:

where:

$$
\text { Irrigation time }(h)=\frac{A I W}{A R}
$$

$\mathrm{AR}=$ application rate,$\left(\mathrm{mm} \mathrm{h}^{-1}\right)$

$$
A R=\frac{1000 \times Q}{L l \times L s}
$$

$\mathrm{Q}=$ sprinkler discharge, $\left(\mathrm{m}^{3} \mathrm{~h}^{-1}\right)$

$\mathrm{L}_{\mathrm{L}}=$ distance between laterals, $(\mathrm{m})$

$\mathrm{Ls}=$ distance between sprinklers, $(\mathrm{m})$

The drip irrigation system used in the experimental farm included an irrigation pump connected to sand and screen filters and venture fertilizer injector, control values, water flow meters, and pressure gauges. The distribution system consisted of PVC pipes forming the mainline $(75 \mathrm{~mm}$ diameter) and manifolds $(63 \mathrm{~mm}$ diameter) for supplying and discharging irrigation water to each plot. Irrigation laterals $(16 \mathrm{~mm}$ in diameter and 30meters in length) with in line emitters spaced $0.3 \mathrm{~m}$ apart with $3.6 \mathrm{~L}$ $\mathrm{h}^{-1}$ flow rate at pressure of $100 \mathrm{kPa}$. A sprinkler irrigation system solid-set type was installed in the experimental site, and composed of PVC pipes of 110 and $75 \mathrm{~mm}$ diameters, which used as main and lateral lines, respectively. The distance between sprinklers was $7 \mathrm{~m}$ and between lateral was $9 \mathrm{~m}$. Fertilizer tanks were placed at the upper end of the main line, which used for nitrogen, phosphorus, and potassium fertilizers application. The actual discharge of sprinkler was $0.5 \mathrm{~m}^{3} \mathrm{~h}^{-1}$.

During land preparation, $15 \mathrm{~m}^{3} / \mathrm{fed}$ of chicken manure was incorporated into the soil surface. N, P and $\mathrm{K}$ fertilizers were applied as recommended for potato production in the area, where $180 \mathrm{~kg} / \mathrm{fed} \mathrm{N}$ (as ammonium nitrate, $33.5 \% \mathrm{~N}$ ), $96 \mathrm{~kg} / \mathrm{fed}$ $\mathrm{K}_{2} \mathrm{O}$ (as potassium sulfate, $48 \% \mathrm{~K}_{2} \mathrm{O}$ ) and $45 \mathrm{~kg} / \mathrm{fed} \mathrm{P}_{2} \mathrm{O}_{5}$ (as phosphoric acid 85\% $\left.\mathrm{P}_{2} \mathrm{O}_{5}\right)$ were injected through the irrigation water in 10 and 5 doses, respectively, for drip and sprinkler irrigation systems. Potato seeds (Spunta variety) were planted on the $15^{\text {th }}$ and the $3^{\text {rd }}$ of November and the tubers were harvested on the $20^{\text {th }}$ and $3^{\text {rd }}$ of March in the $1 \mathrm{st}$ and $2^{\text {nd }}$ seasons, respectively.

Water consumptive use (WCU) values were calculated according to Israelsen and Hansen (1962) using the following equation:

where:

$$
W C U=\sum_{i=1}^{i-4} \frac{\theta 2-\theta 1}{100} \times d \times \rho
$$

$$
\begin{aligned}
\text { WCU } & =\text { water consumptive use or actual } \\
& \text { evapotranspiration, ETa }(\mathrm{cm}) \\
\mathrm{i} & =\text { number of soil layer } \\
\theta 2 & \begin{array}{l}
=\text { soil moisture content } 6 \text { hours after } \\
\text { irrigation, }(\%, \text { by weight })
\end{array} \\
\theta 1 \quad & \begin{array}{l}
=\text { soil moisture content just before } \\
\text { irrigation, }(\%, \text { by weight })
\end{array} \\
\mathrm{d} \quad & =\text { depth of soil layer, }(\mathrm{cm}) \\
\rho \quad & =\text { soil bulk density, }\left(\mathrm{g} \mathrm{cm}^{-3}\right)
\end{aligned}
$$


Crop coefficient $(\mathrm{Kc})$ values were calculated as:

$$
K c=\frac{E T a}{E T p}
$$

where:

$\mathrm{ETa}=$ actual evapotranspiration or water consumptive use $(\mathrm{cm})$

$\mathrm{ETp}=$ potential evapotranspiration $(\mathrm{cm})$

Water utilization Efficiency (WUtE, $\mathrm{kgm}^{-3}$ ) values were calculated according to Jensen (1983) as follows:

$$
\begin{aligned}
& W U_{t} E \\
& =\frac{\text { Potato tuber yield }(\mathrm{kg} / \mathrm{fed})}{\text { Applied irrigation water }\left(\mathrm{m}^{3} / \mathrm{fed}\right)}
\end{aligned}
$$

Starch content of the potato tubers samples under each sub -plot was determined according to Norgia et al. (2008).

The obtained data of yields of fresh and dry potato tubers (ton/fed) and starch percentage were statistically analyzed according to technique of analysis of variance (ANOVA) for the split- plot experimental design as described by Steel and Torrie (1960).

\section{RESULTS AND DISCUSSION Potato fresh and dry matter yields $\left(\right.$ tonfed $\left.^{-1}\right)$, and starch percentage:}

Effect of irrigation systems and irrigation regimes on potato fresh yield, potato dry matter, and starch percentage in sandy soils during the 2008-2009 and 2009-2010 growing seasons is presented in Table 2. Results showed significant effects of the tested variables on potato fresh yield in the $1^{\text {st }}$ and $2^{\text {nd }}$ seasons and on potato dry yield in the $1^{\text {st }}$ season only. The drip irrigation system recorded significant increase in fresh potato yield by 23.0 and $7.0 \%$ in the $1^{\text {st }}$ and $2^{\text {nd }}$ seasons, respectively as compared with sprinkler irrigation system. The $\mathrm{ETp}_{125 \%}$ irrigation regime gave the highest values of fresh potato yield in the two growing seasons. The results indicated, under the experimental conditions, that potato fresh yield increases by increasing amount of irrigation water up to $\mathrm{ETp}_{125 \%}$ in the two growing seasons. The highest yields of potato were 14.325 and 17.902 tonfed $^{-1}$ in the $1^{\text {st }}$ and $2^{\text {nd }}$ seasons, respectively, were obtained from $\mathrm{ETp}_{125 \%}$ irrigation regime with drip irrigation system. The $\mathrm{ETp}_{125 \%}$ irrigation regime produced the highest values of potato dry mater and starch\% reached $\left(2.358\right.$ and 2.975 tonfed $\left.^{-1}\right)$ and (18.8 and18.5\%), respectively, in the $1^{\text {st }}$ and $2^{\text {nd }}$ seasons. Results showed also that, imposing water stress reduced potato fresh yield by $15.4,29.5$, and $38.2 \%$ in the $1^{\text {st }}$ season and by $5.1,17.4$, and $36 \%$ in the $2^{\text {nd }}$ season for $\mathrm{ETp}_{100 \%}$, ETp $75 \%$ and $\mathrm{ETp}_{50 \%}$ irrigation regimes, respectively as compared with $\mathrm{ETp}_{125 \%}$ regime. The obtained results agreed with those reported by Adams and Stevenson (1990); Porter et al. (1999); Faberio et al. (2001); Yuan et al. (2003); Ayas and Korukeu (2010) and Eskandaria et al. (2012).

\section{Water requirements (WR):}

Data in Table 3 indicated that, the highest monthly values of water requirements e.g. 6.6 and $6.0 \mathrm{~cm}$ recorded at February in the $1^{\text {st }}$ and $2^{\text {nd }}$ seasons with all adopted irrigation regimes under sprinkler and drip irrigation systems. For sprinkler system, the total amounts of water requirements were $40.2,37.0,30.5$, and $26.0 \mathrm{~cm}$ in the $1^{\text {st }}$ season, and $42.5,35.5$, 29.0, and $22.5 \mathrm{~cm}$ in the $2^{\text {nd }}$ season for the $E T p_{125 \%}, E T p_{100 \%}, E T p_{75 \%}$, and $E T p_{50 \%}$ irrigation regimes, respectively. For drip irrigation system, the total amounts of water requirements were $35.0,31.1,27.1$, and $23.0 \mathrm{~cm}$ in the $1^{\text {st }}$ season and were 38.6 , $32.2,26.5$, and $21.4 \mathrm{~cm}$ in the $2^{\text {nd }}$ season, for the same respective treatments. Results indicated that average amounts of applied water by drip system were 13 and $8 \%$ less than those applied by the sprinkler system. The obtained results agreed with those reported by Brown (1999) and Ayas and Korukeu (2010). 
Attia, et al.,

Table 2: Average potato fresh yields (ton/fed), potato dry matter (ton/fed), and starch percentage as affected by Sprinkler and Drip irrigation systems and irrigation regimes and interaction, 2005/2009 and 2009/2010 seasons

\begin{tabular}{|c|c|c|c|c|c|c|}
\hline \multirow[t]{2}{*}{ Treatment } & \multicolumn{2}{|c|}{$\begin{array}{l}\text { Potato fresh yield } \\
\quad\left(\text { tonfed }^{-1}\right)\end{array}$} & \multicolumn{2}{|c|}{$\begin{array}{l}\text { Potato dry matter yield } \\
\text { (tonfed }^{-1} \text { ) }\end{array}$} & \multicolumn{2}{|c|}{ Starch percentage } \\
\hline & 2008-2009 & $2009-2010$ & 2008-2009 & $2009-2010$ & $2008-2009$ & $2009-2010$ \\
\hline \multicolumn{7}{|c|}{ Irrigation systems } \\
\hline Sprinkler & 9.429 & 13.965 & 1.758 & 2.658 & 17.7 & 18.1 \\
\hline Drip & 11.600 & 14.943 & 2.370 & 2.726 & 17.9 & 18.3 \\
\hline L.S.D at 0.05 & 0.469 & 0.924 & 0.145 & N.S. & N.S. & N.S. \\
\hline \multicolumn{7}{|c|}{ Irrigation regimes } \\
\hline $125 \% \operatorname{ETp}\left(\mathrm{I}_{1}\right)$ & 13.262 & 16.928 & 2.358 & 2.975 & 18.8 & 18.5 \\
\hline $100 \% \operatorname{ETp}\left(I_{2}\right)$ & 11.222 & 16.073 & 2.103 & 2.857 & 17.9 & 18.2 \\
\hline $75 \%$ ETp $\left(I_{3}\right)$ & 9.350 & 13.981 & 1.917 & 2.697 & 17.5 & 18.6 \\
\hline $50 \%$ ETp $\left(I_{4}\right)$ & 8.197 & 10.836 & 1.877 & 2.238 & 17.0 & 17.4 \\
\hline L.S.D at 0.05 & 0.726 & 0.900 & 0.130 & 0.463 & 0.38 & 0.71 \\
\hline \multicolumn{7}{|l|}{ Interaction } \\
\hline Sprinkler $\mathrm{xI}_{1}$ & 12.200 & 15.955 & 2.416 & 3.000 & 18.2 & 18.4 \\
\hline Sprinkler $\times \mathrm{I}_{2}$ & 9.475 & 14.832 & 1.876 & 2.788 & 18.1 & 18.2 \\
\hline Sprinkler $\times I_{3}$ & 8.475 & 14.055 & 1.878 & 2.642 & 17.3 & 18.3 \\
\hline Sprinkler $\mathrm{x} \mathrm{I}_{4}$ & 7.500 & 11.020 & 1.885 & 2.572 & 17.2 & 18.2 \\
\hline Drip $\times I_{1}$ & 14.325 & 17.902 & 2.836 & 3.366 & 19.4 & 18.4 \\
\hline Drip $\times I_{2}$ & 12.975 & 17.312 & 2.569 & 3.255 & 17.7 & 18.1 \\
\hline Drip $\times I_{3}$ & 10.225 & 13.907 & 2.325 & 2.615 & 17.8 & 18.0 \\
\hline Drip $\mathrm{x} \mathrm{I}_{4}$ & 8.875 & 10.652 & 1.957 & 2.403 & 16.8 & 17.8 \\
\hline L.S.D at 0.05 & 1.024 & 1.269 & N.S. & N.S. & 0.54 & N.S. \\
\hline
\end{tabular}

Table 3. Monthly and seasonal potato water requirements $(\mathrm{cm})$ as affected by irrigation regimes and the two irrigation systems in the two growing seasons

\begin{tabular}{|c|c|c|c|c|c|c|c|c|c|c|c|c|c|}
\hline \multicolumn{2}{|c|}{ Irrigation system } & \multicolumn{6}{|c|}{ Sprinkler } & \multicolumn{6}{|c|}{ Drip } \\
\hline season & $\begin{array}{l}\text { Irrigation } \\
\text { regime }\end{array}$ & Nov. & Dec. & Jan. & Feb. & Mar. & Total & Nov. & Dec. & Jan. & Feb. & Mar. & Total \\
\hline \multirow{4}{*}{ 2008-2009 } & $125 \%$ ETp & 5.8 & 9.7 & 10.0 & 11.5 & 3.2 & 40.2 & 5.1 & 7.3 & 7.5 & 8.6 & 6.5 & 35.0 \\
\hline & $100 \%$ ETp & 5.8 & 8.4 & 9.3 & 10.7 & 2.8 & 37.0 & 5.1 & 6.4 & 6.5 & 7.2 & 5.9 & 31.1 \\
\hline & $75 \%$ ETp & 5.8 & 6.1 & 7.6 & 8.9 & 2.1 & 30.5 & 5.1 & 5.2 & 5.3 & 6.9 & 4.6 & 27.1 \\
\hline & $50 \%$ ETp & 5.8 & 5.8 & 6.0 & 7.0 & 1.4 & 26.0 & 5.1 & 4.4 & 4.6 & 5.5 & 3.4 & 23.0 \\
\hline \multirow{4}{*}{ 2009-2010 } & $125 \%$ ETp & 7.7 & 9.3 & 10.2 & 12.6 & 2.7 & 42.5 & 7.2 & 8.7 & 9.1 & 11.3 & 2.3 & 38.6 \\
\hline & $100 \%$ ETp & 7.2 & 7.6 & 8.2 & 10.3 & 2.2 & 35.5 & 6.8 & 7.0 & 7.4 & 9.1 & 1.9 & 32.2 \\
\hline & $75 \%$ ETp & 6.8 & 5.8 & 6.7 & 7.9 & 1.8 & 29.0 & 6.3 & 5.6 & 5.9 & 7.2 & 1.5 & 26.5 \\
\hline & $50 \%$ ETp & 6.3 & 4.1 & 4.3 & 6.6 & 1.2 & 22.5 & 5.9 & 4.1 & 4.3 & 6.0 & 1.1 & 21.4 \\
\hline
\end{tabular}




\section{Water consumptive use (CU):}

Data in Table 4 indicated that, the highest monthly values of water consumptive use occurred during February in both seasons for all irrigation regimes and the two irrigation systems. For the sprinkler irrigation system, the total water consumptive use values were $29.5,28.9$, 27.2 , and $23.9 \mathrm{~cm}$ in the $1^{\text {st }}$ season and 32.2 , $27.2,22.8$, and $17.2 \mathrm{~cm}$ in the $2^{\text {nd }}$ season, respectively for the $125,100,75$, and $50 \%$ ETp irrigation regimes. While for the drip irrigation system, the total water consumptive use values for the same respective treatments were $27.8,26.5,24.0$, and $20.8 \mathrm{~cm}$ in the first season and were $32.0,26.8,22.4$, and $17.7 \mathrm{~cm}$ in the second season. Results indicated that, decreasing the amount of applied irrigation water increased the amounts of consumed water by potato crop. Also, plants under drip irrigation system were more efficient in consuming water as compared with those under sprinkler system. The 2-year average percentage of CU/WR values under sprinkler system were 74.6, 77.4, 83.9, and $84.2 \%$ for the $\mathrm{ETp}_{125 \%}, \mathrm{ETp}_{100 \%}, \mathrm{ETp}_{75 \%}$, and $E T p_{50 \%}$ irrigation regimes, respectively. For the drip system, the same respective values were $81.2,84.2,86.5$, and $86.6 \%$. The obtained results agreed with those reported by CSSRI (2000), and Ayas and KoruKeu (2010).

\section{Water Utilization Efficiency (WUtE):}

Results in Table 5 represent the effect of irrigation treatments and the two modern irrigation systems (drip and sprinkler) on water utilization efficiency (WUtE) expressed as $\mathrm{kg}$ of potato yield per cubic meter of water requirements. Comparing the values of WUtE under different irrigation regimes and the two irrigation systems reveals that maximum values were obtained from the drip irrigation system in the $1^{\text {st }}$ and $2^{\text {nd }}$ seasons. The highest WUtE average value of $11.37 \mathrm{~kg}$ potato yield $/ \mathrm{m}^{3}$ applied water resulted from the interaction between $\mathrm{I}_{2}$ irrigation treatment and the drip irrigation system. The lowest WUtE average value of $8.03 \mathrm{~kg}$ potato yield $/ \mathrm{m}^{3}$ applied water was recorded from $\mathrm{ETp}_{100 \%}$ irrigation regime under sprinkler irrigation system. These results were in agreement with those reported by Bader (1992); Yuan et al. (2003) and Erdem et al. (2006).

\section{Potential Evapotranspiration (ETp) and crop coefficient $(\mathrm{Kc})$ :}

The calculated monthly potential evapotranspiration and crop coefficient values during the two growing seasons are shown in Table 6 . The $\mathrm{Kc}$ values were calculated based on the monthly actual evapotranspiration $(E T a)$ values measured for $E T p_{125 \%}$ irrigation regime under drip irrigation system which produced the highest potato yields. Results showed that, the monthly ETp values were low at the beginning of the growing season and increased gradually to reach its maximum value in February. This trend is due to the increase in evaporation and air temperature at the experimental site. The developed local potato crop coefficient (Kc) values reflect the relation between crop characteristics as well as the percent of crop cover and the local climatic conditions. Crop coefficient $(\mathrm{Kc})$ values were low at early stages of growth, then increased gradually as the percentage of crop cover increased, and decreased again as plants started to mature. The 2- season average $\mathrm{Kc}$ value 1.19 reached in January. The average of seasonal local crop coefficient value of the two seasons was 0.81 . The obtained results are in agree with those reported by Doorenbos and Pruitt (1984) and CSSRI (2000). 
Attia, et al.,

Table 4. Monthly and total water consumptive use (cm) for potato crop as affected by irrigation treatments and the two irrigation systems in the two growing seasons

\begin{tabular}{|c|c|c|c|c|c|c|c|c|c|c|c|c|c|}
\hline \multicolumn{2}{|c|}{ Irrigation system } & \multicolumn{6}{|c|}{ Sprinkler } & \multicolumn{6}{|c|}{ Drip } \\
\hline season & $\begin{array}{l}\text { Irrigation } \\
\text { regime }\end{array}$ & Nov. & Dec. & Jan. & Feb. & Mar. & Total & Nov. & Dec. & Jan. & Feb. & Mar. & Total \\
\hline \multirow{4}{*}{$\begin{array}{l}2008- \\
2009\end{array}$} & $\mathrm{ETp}_{125 \%}$ & 3.7 & 6.4 & 7.3 & 8.8 & 3.3 & 29.5 & 2.0 & 5.6 & 6.7 & 7.5 & 6.0 & 27.8 \\
\hline & $\mathrm{ETp}_{100 \%}$ & 3.9 & 6.2 & 7.1 & 8.6 & 3.1 & 28.9 & 2.3 & 5.2 & 6.3 & 6.9 & 5.8 & 26.5 \\
\hline & $\mathrm{ETp}_{75 \%}$ & 3.7 & 5.6 & 6.9 & 8.2 & 2.8 & 27.2 & 2.0 & 5.0 & 5.6 & 6.6 & 4.8 & 24.0 \\
\hline & $\mathrm{ETp}_{50 \%}$ & 3.6 & 5.4 & 5.7 & 7.3 & 1.9 & 23.9 & 2.2 & 4.4 & 4.8 & 5.6 & 3.8 & 20.8 \\
\hline \multirow{4}{*}{$\begin{array}{l}2009- \\
2010\end{array}$} & $\mathrm{ETp}_{125 \%}$ & 4.1 & 6.0 & 7.2 & 12.6 & 2.3 & 32.2 & 4.7 & 5.9 & 9.3 & 10.6 & 1.5 & 32.0 \\
\hline & $\mathrm{ETp}_{100 \%}$ & 4.0 & 5.1 & 5.3 & 10.9 & 1.9 & 27.2 & 4.0 & 5.1 & 7.1 & 9.0 & 1.6 & 26.8 \\
\hline & $\mathrm{ETp}_{75 \%}$ & 4.1 & 4.0 & 4.5 & 8.5 & 1.7 & 22.8 & 3.8 & 4.0 & 6.0 & 7.2 & 1.4 & 22.4 \\
\hline & $\mathrm{ETp}_{50 \%}$ & 3.1 & 3.3 & 3.6 & 6.1 & 1.1 & 17.2 & 3.2 & 3.4 & 4.7 & 5.2 & 1.2 & 17.7 \\
\hline
\end{tabular}

Table 5. Water utilization efficiency (kg potato yield $/ \mathrm{m}^{3}$ water requirements) as affected by irrigation treatments and the two irrigation systems in the two growing seasons.

\begin{tabular}{|l|c|c|c|c|c|c|}
\hline \multirow{2}{*}{$\begin{array}{l}\text { Irrigation } \\
\text { regimes }\end{array}$} & \multicolumn{2}{|c|}{$2008-2009$} & \multicolumn{2}{c|}{$2009-2010$} & \multicolumn{2}{c|}{ Average } \\
\cline { 2 - 7 } & $\begin{array}{c}\text { Sprinkler } \\
\text { system }\end{array}$ & $\begin{array}{c}\text { Drip } \\
\text { system }\end{array}$ & $\begin{array}{c}\text { Sprinkler } \\
\text { system }\end{array}$ & $\begin{array}{c}\text { Drip } \\
\text { system }\end{array}$ & $\begin{array}{c}\text { Sprinkler } \\
\text { system }\end{array}$ & $\begin{array}{c}\text { Drip } \\
\text { system }\end{array}$ \\
\hline $\mathrm{ETp}_{125 \%}$ & 7.23 & 9.74 & 8.93 & 11.03 & 8.08 & 10.39 \\
\hline $\mathrm{ETp}_{100 \%}$ & 6.10 & 9.94 & 9.95 & 12.80 & 8.03 & 11.37 \\
\hline $\mathrm{ETp}_{75 \%}$ & 6.62 & 8.98 & 11.55 & 12.48 & 9.09 & 10.73 \\
\hline $\mathrm{ETp}_{50 \%}$ & 6.87 & 9.18 & 11.67 & 12.44 & 9.27 & 10.81 \\
\hline
\end{tabular}

Table 6. Potential evapotranspiration (ETp) and crop coefficient (Kc) for potato crop under drip irrigation in the two growing seasons

\begin{tabular}{|l|c|c|c|c|c|}
\hline \multirow{2}{*}{ Season } & \multicolumn{2}{|c|}{$2008-2009$} & \multicolumn{2}{c|}{$2009-2010$} & \multirow{2}{*}{ Average Kc } \\
\cline { 2 - 5 } & $\begin{array}{c}\text { ETp } \\
\text { (cm/month) }\end{array}$ & Kc & $\begin{array}{c}\text { ETp } \\
\text { (cm/month) }\end{array}$ & Kc & \\
\hline November & 5.0 & 0.40 & 10.2 & 0.46 & 0.43 \\
\hline December & 6.5 & 0.86 & 6.3 & 0.94 & 0.90 \\
\hline January & 6.0 & 1.12 & 7.4 & 1.26 & 1.19 \\
\hline February & 9.2 & 0.82 & 11.5 & 0.92 & 0.87 \\
\hline March & 9.1 & 0.66 & 2.4 & 0.63 & 0.65 \\
\hline Average & & 0.77 & & 0.84 & 0.81 \\
\hline
\end{tabular}




\section{REFERENCES}

Adams, S.S. and D.R. Stevenson (1990). Water management disease development and potato production. Amer. Potato J. 67:3-11.

Ayas, S. and A. Korukeu (2010). Wateryield relationships in deficit irrigated potato J. of Agric. Uludag University. 2: 23-36.

Badr, A.E. (1992). Potato production under drip and sprinkler irrigation systems compared with furrow irrigation. Misr J. Ag. Eng. 9:77-97.

Brown, I.R. 1999. Feeding nine billion. In L. Starke (ed.): State of the world, 1999. W.W. Norton and Co. New York. 230pp.

CSSRI. 2000. Evapotranspiration estimation and crop-coefficients. Technical report of Central Soil Salinity Research Institute, Karnal, India.

Doorenbos, J. and W.O. Pruitt (1984). Crop water requirements. Irrigation and Drainage Paper no. 24, FAO, Rome, Italy.

Erdem, T., Y. Erdem, H. Orta and H. Okursoy (2006). Water-yield relationships of potato under different irrigation methods and regimes. Sci. Agr. (Piracicaba. Braz.). 63: 226-231.

Eskandaria, A., H.R. Khazaie, A. Nezami, M. Kafi, A. Majdabadi and S. Soufizadeh (2012). Effects of drip irrigation regimes on potato tuber yield and quality. Archives of Agronomy and Soil Sci. 2012, 1-9.

Fabeiro, C., F.M. de Santa Olalla and J.A. de Juan (2001). Yield and size of deficit irrigated potatoes. Agric. Water Manage. 48:255-266.

Ferreira, T.C., and M.K.V. Carr. 2002. Responses of potato to irrigation and nitrogen in a hot dry climate, I: Water use. Field Crops Res. 78:51-64.

Ismail, S.M. (2002). Design and Management of Field Irrigation System (In Arabic). $1^{\text {st }}$ Ed., Monsheat EL-Maaref Publication, Alexandria, Egypt.

Israelsen, O.W. and V.E. Hansen (1962). Irrigation principles and practices. $3^{\text {rd }}$
Edit. John Wiley and Sons Inc., New York.

Jensen, M.E. (1983). Design and operation of farm irrigation systems. Amer. Soc. Agric. Eng. Michigan, USA, 827pp.

Kandil, A.A., A.N. Attia, M.A. Badawi, A.E. Sharief and W.A.H. Abido (2011). Effect of water stress and fertilization with inorganic nitrogen and organic chicken manure on yield and yield components of potato. Australian Journal of Basic and Applied Sciences. 5: 997-1005.

Norgia, W., G. Mircea, I. Iosif, D. Delia and M. Camelia (2008). Method to starch content determination from plants by specific weight. Lucrări ştiinŃifice Zootehnie şi Biotehnologii, vol. 41 (1): 814- 818.

Panigrahi, B., S.N. Panda and N.S. Raghuwanshi (2001). Potato water use and yield under furrow irrigation. Irrig. Sci. 20:155-163.

Porter, G.A., G.B. Opena, W.B. Bradbury, J.C. McBurnie and J.A. Sisson (1999). Soil management and supplemental irrigation effects on potato. 1: Soil properties, tuber yield and quality. Agron. J. 91:416- 425 .

Rowe, R.C. (1993). Potato Health Management. APS PRESS, USA,195pp.

Steel, R.G.D. and T.H. Torrie (1960). Principles and procedures of statistics. M.C. Graw Hill, N.Y.

Ünlü, M., R. Kanber, U. Senyigit, H. Onaran and K. Diker (2006). Trickle and sprinkler irrigation of potato in the Middle Anatolian Region in Turkey. Agric . Water Management. 79:43 -71.

Vermeiren, L. and G.A. Jopling (1984). Localized Irrigation. FAO, Irrigation and Drainage Paper no. 36, Rome, Italy.

Yuan, B., S. Nishiyama and Y. Kang (2003). Effects of different irrigation regimes on the growth and yield of drip irrigated potato. Agric. Water Management. 63:153-167.

Zeag, D.E. (1991). The Potato crop in Saudi Arabia, Saudi Potato Development Program. Ministry of Agric. and Water, Riyadh, 180pp. 
تأثير معاملات الري على انتاجية محصول البطاطس فى الاراضي الرملية تحت نظامى الري بالرش والتنقيط

محمود محمد عطية ، عبد الهادي خميس عبدالحليم ، عبد السلام مرغنى عثمان ، محمود عاطف سيا ، حمدي الحسيني خليفة

قسم بحوث المقننات المائية والري الحقلي - معهد بحوث الأراضى والمياه والبيئة - مركز البحوث الزراعية - مصر علئ الملخص العربى (أحسى

أجريت تجربة حقلية بالمزرعة البحثية بقرية على مبارك بمنطقة البستان بغرب النوبارية خلال موسمي النمو 2008-

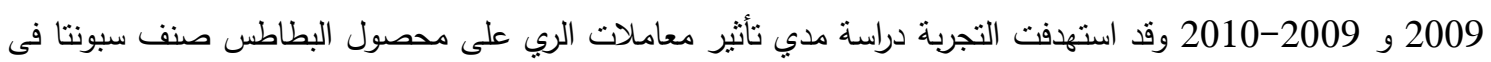
الاراضي الرملية تحت نظامى الري بالرش والتتقيط وكانت معاملات الري كالتالي:-

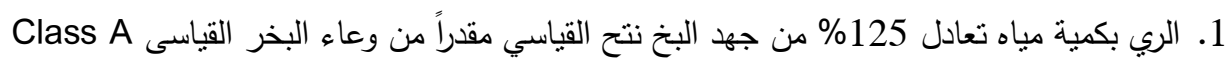

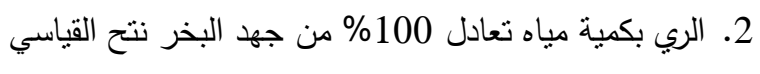

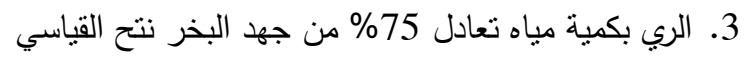

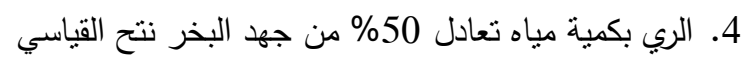

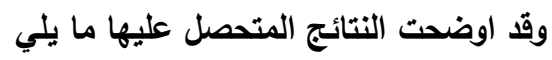

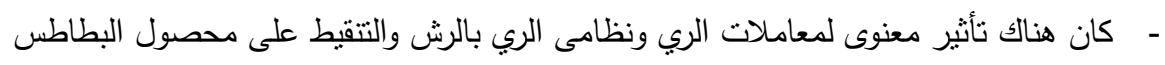

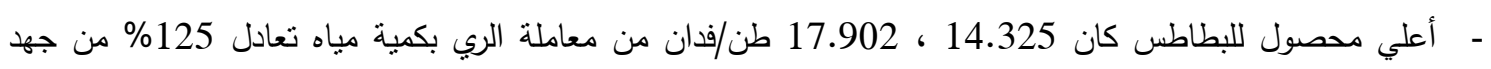

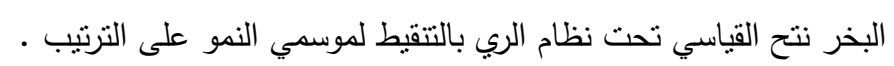

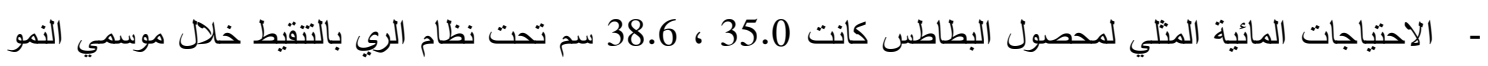
على التزتيب . - الاستهالك المائي لدحصول البطاطس كان 27.8 ، 32.0 سم تحت نظام الري بالتتقيط خلال موسمي النمو على التزتيب.

- أعلي قيمة للكفاءة الاستعمالية لمياه الري المضافة كانت 9.94 ، 12.80 كجم بطاطس لكل م3 مياه مضافة خلال موسمي النمو على الترتيب وذلك من معاملة الري بكمية مياه نعادل 100\% من جهد البخر نتح القياسي وتحت نظام الري بالتتقيط.

- منوسط قيمة معامل النبات (KC) لمحصول البطاطس كان 0.81 وأعلي قيمة لمعامل النبات كانت خلال شهر يناير . 